\title{
ТУРКИЙН ДОТООД БАЙДАЛ, ТӨВ АЗИЙН ОРНУУД, МОНГОЛ УЛСТАЙ ХАРИЛЦАХАД НӨЛӨӨЛӨХ НЬ
}

\section{Ч.Цэрэннадмид}

Бүгд Найрамдах Турк улс анх байгуулагдсан ичагаас эхлэн тус улс гадаад улс төрийн бодлогоо “эх нутагт энх амгаланг тогтоосноор эх дэлхийд энх тайван бий болно” гэсэн Үндсэн ойлголт, зарчмын хүрээнд тодорхойлж ирсэн билээ. Энэ зарчим одоо хэр тус улсын дотоод болон гадаад улс төрийн бодлогын үндсэн зарчим байсаар байна. Өнгөрөгч хэдэн арван жсилийн турш Турк улс, Европьын Холбоотой харилиах харилцаандаа тусгайлан анхаарч, тус холбоонд элсэх, холбогдох шаардлагыг биелүүлэхэд бүх шатанд идэвхи зүтгэл гаргасаар ирсэн тул тус улсын гадаад улс төрийн бодлогын тэргүүлэх чиглэл Европьнн Холбоонд нэгдэх асуудал байсаар ирлээ. Гэвч санхҮY, эдийн засгийн олон хүнд хямрал нүҮрлэсэн сүҮлийн арван жилийн хугаиаанд Турк улсын эдийн засаг хурдацтай хөгжиж, дэлхийн хамгийн хурдан хөгжиж буй эдийн засагтай улс орнуудын нэг боллоо. Харамсалтай нь тус улсын дотоод улс төрийн амьдралд гарч буй огиом өөрчлөлт, үйл явдал, нийгэм-эдийн засгийн нөхиөл байдал нь тус улсын бүс нутагт эзлэх байр суурийг өөрчлөөд зогсохгүй, Төв Азийн бүс нутаг, Монгол Улстай харилцах харилцаанд шинэ уур амьсгал оруулж байна.

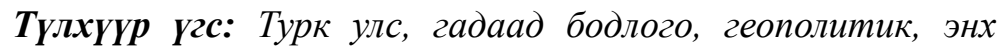
тайван, бүс нутгийн аюулгүй байдал, хамтын ажиллагаа, тогтвортой байдал, Төв Ази, Турк хэлтэн улс орнууд, Монгол Улс 
Анх 1923 онд тусгаар тогтнолоо зарлан тунхаглаж, барууны соёл иргэншил бүхий орчин үеийн Турк улсыг байгуулсан нь Исламын ертөнцөд түүхэн чухал үйл явдал болсон билээ. Шинэ тулгар Бүгд Найрамдах Турк улс эх орныхоо тусгаар тогтнол, аюулгүй байдлыг хангаж, даян дэлхийд энх тайвныг цогцлоох үйл хэрэгт хувь нэмрээ оруулахыг гадаад бодлогынхоо үндсэн зарчим хэмээн тодорхойлжээ. Энэ түүхэн үйл явдлын 95 жилийн ой 2018 онд, 100 жилийн ой 2023 онд тус тус тохиох болно.

Улс төр, нийгэм, эдийн засгийн хөгжлийн түвшин хийгээд шашин, соёлын онцлог шинжээрээ барууны бусад улсуудаас ялгаатай, Османы эзэнт гүрний суурин дээр орчин цагийн Турк орныг цогцлоон хөгжүүлэх үйл явц нэгэн зууны турш үргэлжлэхдээ олон саад бэрхшээлийг даван туулсан ч шинэ мянганы эхэнд эдийн засаг, нийгмийн хөгжлөөрөө бүс нутгийн бусад улс орнуудыг тэргүүлж, эдийн засгийн өсөлтөөрөө дэлхийд 17 дугаарт бичигдэх хүртэлээ хөгжиж гайхамшигт амжилт үзүүлсэн билээ.

Бүгд Найрамдах Турк Улс байгуулагдсаны 100 жилийн ойг тэмдэглэх 2023 онд энэхүҮ амжилтаа ахиулан дэлхийд эхний 10-т бичигдэх хүчирхэг эдийн засагтай орон болох зорилт дэвшүүлээд байна. ${ }^{1}$ Турк улсын эдийн засаг, улс төр, соёл боловсрол, нийгмийн хүрээнд сүүлийн арав гаран жилийн хугацаанд гарсан томоохон өөрчлөлтүүд нь зөвхөн улс үндэстний дотоод хүчин зүйлс, хөгжлийн оновчтой бодлогоос хамаарах төдийгүй тус улсын гадаад бодлогын зарчимын шинэ чиг шугам, түүнийг хэрэгжүүлэх үйл явцтай холбоотой юм. Улс орноо ойрын 10 жил буюу дунд хугацаанд хөгжүүлэх хөгжлийн бодлого төлөвлөлт нь тус улсын гадаад улс төрийн харилцаа, гадаад бодлого, бүс нутагт эзлэх байр суурьт ч томоохон өөрчлөлтүүдийг авчрах магадлалтай гэдгийг судлаачид ${ }^{2}$ тэмдэглэж байна.

Гадаад бодлогын залгамж шинж, цаашид гарч болох өөрчлөлтийн хандлагыг судлан тодорхойлохын тулд түүхэн туршлагын болон

1 О.Батхишиг, Гуравдагч хөршийн бодлого ба Монгол, Туркийн харилиаа “Тззхийн уеуд дэх Турк-Монголын харилцаа” ОУ-ын бага хурал, 2014.11.11 Анкара хот

2 "Assessing Turkey`s Foreign Policy in the Region: Domestic Factors and External Influences" - A policy discussion with Birol Başkan, Assistant Professor at Georgetown University School of Foreign Service, Turan Kayaoğlu, Visiting Fellow, Sinan Marufoğlu, Associate Professor, the Department of Humanities at Qatar University, May, 2012. 
өнөөгийн бодит байдлын дүн шинжилгээ чухал. Иймээс энэхүү товч өгүүлэлд анх парламентын бүгд найрамдах засаглалын хэлбэрийг сонгож, нийгэм, улс төр, эдийн засаг гэх мэт бүх салбарт өөрчлөлт, шинэчлэлт өрнөсөн туршлага, сургамжийг тоймлон дүгнэж, 2000 оны эхэн үеэс дотоод улс төрийн амьдралд гарч эхэлсэн өөрчлөлт, засаглалын хэлбэрийг өөрчлөх гэсэн оролдлогууд болон гадаад бодлогын тэргүүлэх чиглэл, тэр дундаа Төв Азийн бүс нутагт чиглэсэн гадаад бодлогын өөрчлөлт, хандлагын талаар хөндөх болно. Чингэхдээ Турк улсын Төв Азийн бүс нутагт чиглэсэн бодлогын хүрээнд Монгол-Туркийн харилцаа ямар түвшинд хөгжиж байгаа, цаашид онцлон анхаарах шаардлагатай асуудлуудын талаар судлаачийн хувьд санаа бодлоо илэрхийлэх оролдлого хийлээ.

\section{Нэг. Өөрчлөлт, шинэчлэлийн туршлага, сургамжийн тухайд}

Дэлхийн 1-р дайны дараа Османы эзэнт гүрний суурин дээр тусгаар тогтносон Бүгд Найрамдах Турк улс байгуулах үйл хэрэгт онцгой хувь нэмэр оруулсан хүн бол цэргийн жанжин, тус улсын анхны Ерөнхийлөгч Мустафа Кемал Ататурк юм. Туркийн ард түмний үндэсний эцэг болох энэ хүн 1923 оны 10 дугаар сарын 29-нд тусгаар тогтносон Турк улсын анхны Ерөнхийлөгч болж нийт 4 удаа ерөнхийлөгчөөр улиран сонгогдсон байдаг. Ататуркийн байгуулсан гавъяа их, нийгмийн бүх салбарт шинэчлэл хийсэн, шинэ тусгаар улсыг барууны чиг баримжаатай хөгжлийн замаар замнах эхлэлийг тавьсан хүн юм. Ататуркийн байгуулсан Ардын Бүгд Найрамдах Нам засгийн эрхэнд байх хугацаанд төр, шашны хэргийг тусгаарлах, шинэ цагаан толгой зохиож, Турк хэлийг албан ёсны хэл болгох, Исламын шариатын хуулийг халж, хууль, шүүхийн тогтолцоог бүхэлд нь өөрчлөх, аж үйлдвэржүүлэх гэх зэргээр нийгэм, эдийн засгийн бүх салбарт шинэчлэлүүдийг эхлүүлж, хэрэгжүүлж чадсан бөгөөд барууны чиг баримжаатай Европын орон болох зорилгодоо хүрэхийн тулд 1960 аад оноос эхлэн тус улсын гадаад бодлогын тэргүүлэх чиглэл нь Европ тивд бүрэлдэн бий болж буй эдийн засаг, худалдаа аюулгүй байдлын асуудлаар интеграцид нэгдэх буюу хожмын Европын Холбоонд элсэх явдал хэмээн тодорхойлсон юм. ИйнхүҮ 
сүүлийн 30 гаран жил Европын Холбоонд элсэх нь Турк улсын гадаад бодлогын тэргүүлэх чиглэл байсаар байна.

Ерөнхийлөгч Режеп Тайп Эрдоганы 2001 онд байгуулсан Шударга ёс, хөгжлийн нам тус улсын засгийн эрхэнд 2002 онд гарснаас хойш, Европын холбоонд элсэх гадаад бодлогын уламжлалаа хэвээр хадгалахаас гадна Евро Азид чиглэсэн гадаад бодлогын зорилго зорилтоо түлхүҮ хөгжүүлэхэд тусгайлан анхаарах болно хэмээн намын мөрийн хөтөлбөртөө тусгасан байдаг ${ }^{3}$. Шударга ёс, хөгжлийн нам засгийн эрхийг барьсан өнгөрөгч 15 жилийн хугацаанд тус улсын эдийн засаг, нийгмийн салбарын хөгжил хурдацтай нэмэгдэж, дэд бүтцийн салбарууд эрчимтэй хөгжиж эхэлсэн боловч дотоод улс төрийн амьдралд томоохон өөрчлөлт, шинэчлэлтүүд хийгдэж эхэлсэн билээ.

Гэвч эдгээр өөрчлөлт, шинэчлэлийн жилүүд дотоод улс төрийн амьдралыг харьцангуй тогтворгүй, сөргөлдөгч хүчнүүдийн хооронд ширүүн мэтгэлцээн, тэмцэл өрнөсөн он жилүүд болсон юм.

1923 оноос хойш засаглалын бүгд найрамдах хэлбэрийг сонгож, 1950 оноос өнөөг хүртэл улс төрийн олон намын тогтолцоотой байгаа Турк улсад өмнө нь Ерөнхийлөгчийг Туркийн Үндэсний Их Хурал сонгодог байсан бол 2007 онд Үндсэн хуульд өөрчлөлт оруулж, Ерөнхийлөгчийг ард нийтийн санал хураалтаар сонгодог болов. 2014 оны наймдугаар сард болсон Ерөнхийлөгчийн сонгуульд 2002 оноос хойш Ерөнхий сайдын албыг хашиж ирсэн Режеп Тайип Эрдоан нийт сонгогчдын 51,8 хувийн ${ }^{4}$ санал авснаар ард түмний бүх нийтийн санал асуулгаар сонгогдсон анхны Ерөнхийлөгч болов. Маш богино хугацаанд өрнөсөн Туркийн улс төрийн удирдлагын түвшин дэх өөрчлөлтийг ардчиллын амжилт гэж зарим судлаачид дүгнэдэг.

ИйнхүY парламентийн бүгд найрамдах засаглалтай Турк орныг ерөнхийлөгчийн бүгд найрамдах засаглалтай орон болгох санал, санаачлага 2007 оноос эхэлсэн бөгөөд 2016 оны 7 дугаар сард цэргийн эрхтнүүд засгийн эрхийг авах оролдлого хийсэн нь Үндсэн хуулиндаа өөрчлөлт оруулж, ерөнхийлөгчийн бүгд найрамдах улс

3 http://www.akparti.org.tr/site/akparti/parti-programi\#bolum

4 БНТУ-ын Сонгуулийн Ерөнхий Хороо http://www.ysk.gov.tr/ysk/content/conn/ YSKUCM/path/Contribution\%20Folders/HaberDosya/2014CB-Kesin-416_d_Genel. pdf 
болох нь улс төрийн тогтвортой байдлыг бий болгох, аюулгүй байдлаас сахин хамгаалахад зайлшгүй хэрэгтэй өөрчлөлт юм гэж үзэх бас нэг үндэслэл болсон байх магадлалтай.

2017 оны 4 дүгээр сарын 16-ний өдөр Туркийн ард түмэн парламентын БН улс хэвээр байх уу, эсвэл Үндсэн хуулиа өөрчлөн, ерөнхийлөгчийн засаглалтай орон болох уу гэдгээ шийдсэн. Энэ санал асуулга бол 1923 онд Бүгд Найрамдах Турк улс байгуулагдаж байсан цагаас өнөөдрийг хүртэл өрнөсөн дотоод улс төрийн амьдралын хамгийн чухал, шийдвэрлэх үйл явдал байлаа. Энэ сонгуулиар Туркийн ард түмэн Үндсэн хуулинд өөрчлөлт оруулахыг дэмжиж, өнөөгийн ерөнхийлөгч Режеп Тайп Эрдоган ерөнхийлөгчөөр 2 дахь удаагаа улиран сонгогдсон бөгөөд 2029 он хүртэл тус улсыг тэргүүлнэ гэж судлаачид, олон улсын ажиглагчид харж байгаа юм.

2017 оны 4 дүгээр сард болсон ард түмний санал асуулгаар Үндсэн хуульд нийт $18^{5}$ зүйлийн өөрчлөлт оруулахаар төлөвлөж байсан бөгөөд эдгээрээс хамгийн их анхаарал татаж байгаa өөрчлөлтөд Үндсэн хуулийн Төрийн тэргүүн засгийн газрын тэргүүн байх, Ерөнхийлөгч төсөв өргөн барих, Сайд нарын танхимийг татан буулгах, шүүх, прокурорын байгууллагын ажилтнуудын томилгоонд Ерөнхийлөгч оролцох зэрэг өөрчлөлтүүд багтсан байна.

Үндсэн хуулийн өөрчлөлтийг дэмжигчдийн хувьд энэ шинэ тогтолцоо Турк улсыг илүY хүчирхэг болгож, аюулгүй байдал сайжирна гэж үзэж байгаа юм. Харин эсэргүүцэгчдийн хувьд эрх мэдлийн тэнцвэр алдагдана, хууль тогтоох байгууллагын эрх мэдэл хумигдана, шүүх болон гүйцэтгэх засаглал нэг хүний гарт төвлөрснөөр нэг хүнийг тахин шүтэх, нэг хүний дарангуйллын үе эхлэнэ хэмээн эмээж байгаа юм.

ИйнхүҮ дотоод улс төрийн амьдралд гарсан өөрчлөлт, шинэчлэл тус улсын гадаад ертөнцтэй харилцах харилцаанд нөлөө үзүүлэх нь гарцаагүй.

Сүүлийн жилүүдэд буюу ерөнхийлөгчөөр сонгогдсон 2014 оны 8 дугаар сараас хойш Тайп Эрдоган олон нийтийн хэвлэл мэдээллийн

5 http://www2.tbmm.gov.tr/d26/2/2-1504.pdf - Туркийн Үндэсний Их Хурлын цахим хуудас

http://anayasadegisikligi.barobirlik.org.tr/Anayasa_Degisikligi.aspx $\quad-\quad$ Туркийн Хуульдын Холбооны цахим хуудас 
хэрэгслээр хэд хэдэн удаа Европын Холбоонд элсэх нь Турк улсын өмнө байгаа цорын ганц сонголт биш, бусад бүс нутгийн интеграц, эдийн засаг, аюулгүй байдлыг хангах зорилго бүхий олон улсын өөр механизмуудад нэгдэн орох боломж Турк улсын өмнө нээлттэй байгааг илэрхийлж эхэлсэн билээ.

Нэг үе хөгжлийн шилдэг загвар хэмээн нэрлэгдэж байсан Европын Холбоо 2010 оноос хойш санХүҮ-эдийн засгийн гүн гүнзгий хямралд орж, Евро бүс цаашилбал, Европын Холбооны хувь заяа хэрхэх тухай асуудал тулгарч байгаа билээ. Үүнтэй уялдан, Турк улсын дотоод улс төр, нийгмийн хүрээлэл дунд Европын Холбоонд элсэх нь зөв эсэх, ШХАБ зэрэг Ази, тэр дундаа Төв Азид чиглэсэн бүс нутгийн хамтын ажиллагааны механизмд нэгдэх, харилцаагаа сайжруулах нь Турк улсад ашигтай эсэхийг нухацтай хэлэлцэж, төрийн өндөр дээд албан тушаалтнууд ч ийм агуулгатай мэдэгдлүүд хийх болов.

Туркийн ерөнхийлөгч Рэжэп Тайп Эрдоган, 2016 онд болсон төрийн эргэлт хийх оролдлогын дараа Анадолу агентлагт өгсөн ярилцлагадаа “Бидний төлөө хуруугаа ч хөдөлгөхгүй байгаа барууны орнуудыг хүлээж цөхөрлөө. Турк улс Европын Холбооны үүдийг сахисаар 53 жилийг өнгөрүүлсэн. Одоо бид тэднийг хүлээхгүй, өөрсдийн замаар явна. Тэд ч өөрсдийнхөөрөө замнах байж”б хэмээжээ.

ИйнхүҮ тус улсын гадаад бодлогын тэргүүлэх чиглэл байсан Европын Холбоонд элсэх асуудал хойш тавигдаж, бүс нутгийн өөр механизмийг сонголт гэж харвал тус улсын Төв Азид чиглэх гадаад бодлогын зорилт, чиглэл тэр хэмжээнд өөрчлөгдөх магадлал өндөр билээ.

\section{Хоёр. Төв Азид чиглэсэн бодлого ба Монгол Туркийн харилцаа}

Турк улс аль эртнээс Кавказ болон Төв Азид онцгой байр суурь эзлэхийг эрмэлзэж байсан. Тус улсын Төв Азид чиглэсэн гадаад бодлогын үндсийг Түрэг хэлтэн улсуудын чуулга уулзалт гэдгийг зохион байгуулж, Төв Азийн бүгд найрамдах улсуудыг ахан дүүсийн

6 Х.Эрдэнэзаяа, “Өдрийн сонин”, 2016 оны 10 дугаар сар. “Эрдоган: Барууныхан Туркэд сайн үйл хийсэнгүй” 
Туркийн дотоод байдал, Төв Азийн орнууд, Монгол улстай харилцахад нөлөөлөх нь

хувиар дэмжихээ илэрхийлж, улс төр, нийгмийн хөгжлийн загвараа тодорхойлоход нь туслах, туршлагаа хуваалцах гэсэн үндсэн 3 хүчин зүйлтэй холбон тайлбарлаж болох юм.

1990-1995 онд энэ бүс нутагт Туркууд байр сууриа бэхжүүлэх гэж багагүй оролдлого хийсэн боловч нэгдүгээрт, Төв Азийн бүгд найрамдах улсуудын аливаа нэг том хүчний нөлөөнд дахин орохоос сэрэмжилсэн хандлага, хоёрдугаарт тухайн цаг үед Турк улсын эдийн засгийн чадавхи төдийлөн хангалттай бус байсан, гуравдугаарт хэдий шашин, соёл, зан заншил ойролцоо боловч хүн ардын боловсролын түвшин, нийгмийн амьдралын хэв маяг, менталитетийн ялгаатай байдал нь Туркууд орон нутгийн иргэдтэй ойлголцоход бэрхшээлтэй байдлыг үүсгэж байв ${ }^{7}$. Ялангуяа, аль нэг том хүчний нөлөөнд дахин орохоос сэрэмжилсэн хандлагыг судлаачид Турк улстай харилцаагаа хөгжүүлэхэд саад болсон үндсэн шалтгаануудын нэг гэж үздэг. Тухайлбал, Удо Б.Баркманн: Төв Азийн шинэ улсууд бие биенээсээ хол хөндий хэвээр байж, өөр өөрсдийн өвөрмөц мөн чанарыг онцгойлон дөвийлгөхийн дээр, үндэстний мөн чанараа олж танихад нь Туркийн зүгээс ямар нэг нөлөө үзүүлэх вий гэж эмээдэг байсан ч байж болзошгүй хэмээжээ. ${ }^{8}$ Ийнхүү 2000-д оны эхэн үе хүртэл Турк улсад Төв Азид чиглэсэн тогтвортой, хамгийн гол нь урт хугацаанд баримтлах бодлого байгаагүй. Туркууд энэ бүс нутаг дахь байр сууриа алдсан ч гэлээ зайгаа тавьж өгөөгүй байна.

Эрдоганы Шударга Ёс, Хөгжлийн нам засгийн эрхэнд гарсан 2000-аад оны эхэн үеэс эхлэн өнгөрөгч 15 жилийн хугацаанд Туркийн Төв Азийн орнуудтай харилцаа идэвхижиж, эдийн засаг, эрчим хүч, соёл боловсрол хүмүүнлэгийн салбарт мэргэшсэн институцээр дамжуулан хамтын ажиллагаагаа эрчимжүүлж чадлаа. Харамсалтай нь 2016 онд Турк улсад болсон цэргийн эргэлт хийх оролдлогын дараагаар Туркийн Засгийн газар Төв Азийн орнууд дахь Ф.Гүлэний санхүүжүүлтээр үйл ажиллагаагаа явуулдаг сургуулиудыг хаах хүсэлт гаргасан боловч Казакстан, Киргизстан зэрэг улсууд эдгээр

7 К.Дэмбэрэл, Д.ОдхүҮ, Д.Шүрхүу, М.Хурметхан, Төв Азийн геополитик ба Монгол Улс, Улаанбаатар, 2005, 9 дүгээр тал.

8 Удо Б. Баркманн, “Төв Азийн геополитикийн орчны хувьсал ба Монгол Улсын аюулгүй байдал” эрдэм шинжилгээний өгүүлэл, Монгол Улсын Үндэсний Аюулгүй байдлын гадаад дотоод орчны судалгаа, дүн шинжилгээ, Улаанбаатар хот, 2014, 200 дугаар тал. 
сургуулийг хаах боломжгүй хэмээн мэдэгдсэн нь хоёр талт харилцаа муудахад тодорхой хэмжээнд нөлөөлсөн байна.

Харин Монгол, Туркийн харилцаа идэвхижиж харилцан элчин сайдын яамдаа байгуулж эхэлсэн үе бол 1996, 1997 он бөгөөд улс төр, нийгэм соёлын харилцаа эрчимтэй хөгжиж эхэлсэн юм.

1998-2015 он хүртэл өндөр дээд хэмжээний айлчлал 8 удаа болсон байна ${ }^{9}$. Шүүх, цагдаа, статистик, онцгой байдал гэх мэт олон байгууллагад мэргэжил, арга зүйн дэмжлэг үзүүлэх, урт богино хугацааны сургалтанд хамруулах ажлыг идэвхитэй хэрэгжүүлж байна. 1990-ээд оноос эхлэн хоёр талын харилцаа соёл, боловсрол, хүмүүнлэгийн салбарт эрчимтэй хөгжиж эхэлсэн байна. ТИКА байгууллагын шугамаар 2004 оноос нийт 30 орчим сая ам.долларын тусламж үзүүлсэн бөгөөд эдгээрийн дийлэнх нь дэд бүтэц, сургууль, эмнэлэг, хүмүүнлэгийн тусламжийн арга хэмжээнд чиглэгджээ.

Харин томоохон хэмжээний хөрөнгө оруулалт, хамтарсан үйлдвэр зэрэг эдийн засгийн хамтын ажиллагаа эхлэлийн төдий байгааг анхаарах хэрэгтэй.

Хүснэгт 1. Хоёр талын худалдаа, эдийн засгийн харилцаа сая.ам.доллар

\begin{tabular}{lll}
\hline $\mathbf{O н}$ & Экспорт & Импорт \\
\hline $\mathbf{2 0 1 1}$ & 43,4 & 3,0 \\
\hline $\mathbf{2 0 1 2}$ & 35,8 & 0,1 \\
\hline $\mathbf{2 0 1 3}$ & 48,2 & 0,4 \\
\hline $\mathbf{2 0 1 4}$ & 35,4 & 0,1 \\
\hline $\mathbf{2 0 1 5}$ & 23,3 & 0,5 \\
\hline
\end{tabular}

Эх сурвалж: Туркийн Статистикийн Институт

Бид Турк орныг гуравдагч хөршөөр тодорхойлж, Монгол дахь бодит ашиг сонирхлыг бий болгохыг гадаад бодлогын үзэл баримтлалдаа тусгасан. Туркийн талаас ч Тайп Эрдоган 2013 онд

9 О.Батхишиг, Д.Анхбаяр, Дипломат харилцаань 40 жилийн ой: Монгол, Туркийн харилцааны хөгжилт, Анкара, 2014. 
Монгол Улсад ерөнхий сайдын хувиар айлчилж, хамтарсан мэдэгдэл хийхдээ Монгол, Туркийн хооронд иж бүрэн түншлэлийн харилцаа бодитой хэрэгжиж байна, одоо харилцааны түвшинг ахиулж, “стратегийн түншлэл”-д хүргэх хэтийн зорилтыг дэвшүүлэх ёстойг ${ }^{10}$ тэмдэглэсэн байдаг.

Өдгөө дэлхий дахинаа улс төр - эдийн засгийн тив дамнасан хоёр том бүтэц бий болсон бөгөөд эдгээр нь Америк төвтэй Хоёр далайн хамтын нийгэмлэг, нөгөөх нь Их Евроазийн их тивийн хамтын нийгэмлэг гэж ойлгож болно. ${ }^{11}$ Хоёр дахь хамтын нийгэмлэг нь Монголын яг эргэн тойронд төлөвшиж байна. Гуравдагч хөршөө эрэлхийлэн, төлөвшүүлэх, хөгжүүлэх идэвхитэй бодлогын хүрээнд манай улс зөвхөн эхний хамтын нийгэмлэгтэй холбогдох гэж хичээх бус Их Евроазийн хэмээн оросуудын нэрлээд буй тэрхүү том эвсэлд ШХАБ, Евроазийн Эдийн засгийн холбоо, Торгоны замын эдийн засгийн бүслүүр багтана хэмээн оросын судлаачид үздэг. Энэ мэт улс төр-эдийн засаг, аюулгүй байдлын хамтын нийгэмлэгт Монгол Улсын оролцоо, төлөөлллийг бий болгох, дэмжлэг үзүүлэхэд Турк улс хүчтэй хамтрагч, дэмжигч байх боломжтой.

\section{Дүгнэлт}

Даяаршлийн эрин үеийн олон улсын харилцаанд өөрийн гэсэн байр сууриа эзэлсэн Турк улс, Өрнө Дорныг холбож, бүс нутаг хооронд харилцан ойлголцлыг хангах олон тулгуурт гадаад бодлого баримтлагч улсын хувьд, дэлхий нийтийн өмнө тулгараад буй энх тайван, аюулгүй байдлыг сахин хамгаалах, алан хядах ажиллагаа, үй олноор нь хөнөөх зэвсэг, хууль бус цагаачлалын асуудлаар өнгөрөгч арав гаран жилийн турш голлох үүрэгтэй оролцож ирлээ.

Турк, Монгол хоёр улс бол угсаа гарал эртний түүх, соёл, хэлний язгуураараа ойролцоо, бидний хэлдэгээр “элэг нэгтэй” ард түмэн учраас манай хоёр орны харилцаа бүс нутгийн өөр бусад улс орнуудтай харьцуулахад өвөрмөц онцлогтой байх ёстой. Гэвч түүх

10 Мөн тэнд

11 Д.Баярхүу, “Оросын Элчин сайдын үхэл төвийг сахихыг дахин сануулав”, 2016.12.23. www.bayarkhuu.niitlelch.mn 
соёл, хэл ойролцоо гээд сэтгэлийн хөөрлөөр хандаж болохгүй юм гэдгийг 1990 - ээд оны Туркийн Төв Азийн орнуудын харилцаагаа бэхжүүлэх гэсэн бүтэлгүй оролдлого харуулж байна.

Тиймээс юуны өмнө Төв Азийн орнуудын туршлагаас сургамж авах, хоёр орны ард түмэн, нийгмийн амьдралын онцлог шинжийг нарийн судласны үндсэн дээр сайн хөгжихгүй байгаа эдийн засаг, шинжлэх ухаан гэх мэт салбарын харилцаагаа хөгжүүлэх, улмаар иж бүрэн түншлэлийн харилцаанаас стратегийн түншийн түвшинд хүргэх бэлтгэлийг хангах нь зүйтэй болов уу.

ИйнхүҮ хоёр талт харилцаагаа шинэ түвшинд гаргаж чадвал хэтийн ирээдүйд ШХАБ, Шинэ Торгоны зам гэх мэт Евроазийн худалдаа, аюулгүй байдлын интеграцад нэгдэхэд харилцан биенээ дэмжих боломж гарахыг үгүйсгэхгүй.

\section{Ном зүй:}

Англи, Турк хэлээр:

1. Лозаны гэрээ: https://www.britannica.com/event/Treaty-ofLausanne-1923

2. Ismael,Tareq,Y., Aydin, Mustafa, Turkish Foreign Policy in the 21st century: Changing role in World Politics, London, 2004.

3. Prof. Dr. E. Fuat Keyman, İstanbul Politikalar Merkezi Direktörü ve Sabancı Üniversitesi Öğretim Üyesi .http://www.aljazeera.com. tr/gorus/15-temmuz-sonrasi-turkiye-nasil-yonetilmeli

4. БНТУ-ын Сонгуулийн Ерөнхий Хороo http://www.ysk.gov. tr/ysk/content/conn/YSKUCM/path/Contribution\%20Folders/ HaberDosya/2014CB-Kesin-416_d_Genel.pdf

5. Dr.Prof.Faruk Sonmezoglu, II Dunya Savasi'ndan Gunumuze Turk Dis Politikasi, Istanbul, 2006.

6. KONA, Gamze, The Social, Political and Economic Problems Central Asian Republics Faceand The Role of Turkey in The Central Asian Region, Istanbul, 2006.

7. Mango, Andrew, Ataturk: The Biography of the Founder of Modern Turkey, New York, 1999. 
8. Baskin Oran, Turk dis politikasi Kurtulus savasindan bugune Olgular, Belgeler, Yorumlar, 2008, Istanbul,

9. Muherrem Ekis, Turkiyenin Asya Politikasi, TASAM, Ankara, 2009.

10. Ainur Nogayeva, OrtaAsyada ABD, Rusya, Cin stratejik denge arayislar, USAK, Ankara, 2011

11. Turkiyenin Kafkasya, ve Orta Asya ulkeleri ile Siyasi-Iktisadi ve Kulturel Iliskisi, Ankara, 2014

12. "Perceptions" Journal of International Affairs, Center for Strategic Research, Ministry of Foreign Affairs, 2016 Volume XIX, number 1

Монгол хэлээр:

1. Д.Батсайхан, “Монгол Туркийн харилцаа”, Анкара, 2009.

2. О.Батхишиг, Д.Анхбаяр “Дипломат харилцааны 40 жилийн ой: Монгол, Туркийн харилцааны хөгжилт”, Анкара, 2014.

3. К.Дэмбэрэл, Д.Одхүү, Д.Шүрхүү, М.Хурметхан, “Төв Азийн геополитик ба Монгол Улс", Улаанбаатар, 2005.

4. Монгол Улсын Үндэсний Аюулгүй байдлын гадаад дотоод орчны судалгаа, дүн шинжилгээ, Улаанбаатар хот, 2014. 


\section{IMPACT OF TURKEYS \\ DOMESTIC POLITICS ON ITS COOPERATION WITH CENTRAL ASIAN REPUBLICS AND MONGOLIA}

Ch.Tserennadmid

Turkey's foreign policy agenda has been marked by the principle of "peace at home and peace at world" since the foundation of the Republic of Turkey; this principle is the fundamental basis of domestic and foreign policies. For decades, EU-Turkey relations had largely been marked by Turkey's membership aspirations and its foreign policy agenda was very much oriented towards the EU's. In last decade, Turkey has gone from a financial crisis to having one of the fastest growing economies in the world. However, recent developments in the political and socio-economic situation in Turkey, is now reshaping Turkey's role in the regional geopolitics as well its bilateral relations with Central Asian Republicsand Mongolia.

Key words: Turkey, Foreign policy, geopolitics, peace and regional security, cooperation and stability, Central Asia, Turkic language speaking countries, Mongolia, bilateral relations. 